Check for updates

Cite this: Chem. Commun., 2019, 55,8317

Received 29th March 2019,

Accepted 24th June 2019

DOI: $10.1039 / c 9 c c 02450 f$

rsc.li/chemcomm

\section{Functionalisation of isoindolinones via a calcium catalysed Hosomi-Sakurai allylation $\dagger$}

\author{
Ashley J. Basson and Mark G. McLaughlin (D) *
}

\begin{abstract}
A rapid and functionally tolerant calcium catalysed Hosomi-Sakurai reaction has been realised. Employing 1 mol\% calcium, allylated isoindolinones can be synthesised in high yields and the reaction is shown to be tolerant to a range of medicinally relevant functional groups including heterocycles. The synthetic utility of the reaction has been shown, and a plausible reaction mechanism is provided.
\end{abstract}

Isoindolinones are a common structural motif found in both drugs and natural products alike (Fig. 1). ${ }^{1}$ For example, lenalidomide is used in the treatment of cancer, ${ }^{2}$ taliscanine has been shown to have potential as treatment for neurological disorders, ${ }^{3}$ and zopiclone is an approved treatment for insomnia. Furthermore, investigational compounds such as A1 act as inhibitors of the MDM2-p53 protein-protein interaction. ${ }^{4}$

Due to their pronounced biological activities against a range of disease targets, their synthesis has attracted the attention of numerous synthetic chemists (Fig. 2). ${ }^{5}$ Of particular interest is the development of catalytic transformations to produce these important scaffolds. Copper, ${ }^{6}$ palladium, ${ }^{7}$ rhodium, ${ }^{8}$ platinum ${ }^{9}$ and other Lewis acids ${ }^{10}$ have found use in the synthesis of a wide range of isoindolinone scaffolds. Although these methods are useful, many of them rely on the ready access to functionalised building blocks, as well as typically producing mono-functionalised isoindolinones. Furthermore, although elegant, many of the procedures suffer from functional group intolerances, particularly functional groups with relevance in medicinal chemistry. ${ }^{11}$

During the course of a medicinal chemistry program focused on the development of inhibitors against a metabolic disease target, we required access to a range of substituted isoindolinones bearing a functional group handle for further exploitation. Due to our groups' burgeoning interest in the use of calcium as a sustainable catalyst in synthesis, ${ }^{12}$ we decided

Faculty of Science \& Engineering, Department of Natural Sciences, Manchester Metropolitan University, Chester Street, Manchester, M1 5GD, UK.

E-mail:m.mclaughlin@mmu.ac.uk

$\dagger$ Electronic supplementary information (ESI) available: Full experimental conditions and copies of spectra are available. See DOI: 10.1039/c9cc02450f

to explore the use of 3-hydroxyisoindolinones as easily prepared precursors to $N$-acyliminium ions. We reasoned that through catalytic dehydration, these reactive intermediates could be produced and subsequently trapped by an allyl nucleophile. ${ }^{13}$ We started our investigation on model substrate 1a, employing a range of differing calcium catalysts and additive to effect the desired transformation (Fig. 3). We surveyed a range of calcium salts to determine the most appropriate source for the catalytic reaction, and saw no reaction with either $\mathrm{CaCl}_{2}$ or $\mathrm{Ca}(\mathrm{OH})_{2}$. Interestingly we saw a stoichiometric reaction when $\mathrm{Ca}\left(\mathrm{O}^{\mathrm{i}} \mathrm{Pr}\right)_{2}$ was used, with yield increasing as loading increased.

Gratifyingly, when $\mathrm{Ca}\left(\mathrm{NTf}_{2}\right)_{2}$ was employed as a catalyst, ${ }^{14}$ we isolated $15 \%$ of the desired product after 1 hour. ${ }^{10 c}$ Addition of $n \mathrm{Bu}_{4} \mathrm{NPF}_{6}$ further improved the yield, ${ }^{15}$ as did changing the solvent to 1,2-DCE. Further attempts at improving the reaction were not successful, including performing the reaction in a binary mix of solvents. To ensure the reaction required a calcium salt, we attempted the reaction using $\mathrm{HNTf}_{2}$, however no reaction was observed.

With these optimised conditions in hand, we probed the substrate scope of the reaction (Fig. 4). As observed, both

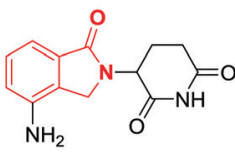

Lenalidomide

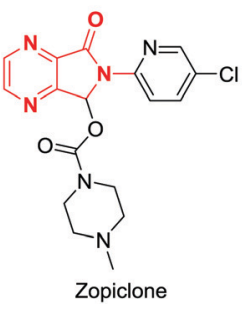

Fig. 1 Biologically relevant $\gamma$-lactams.
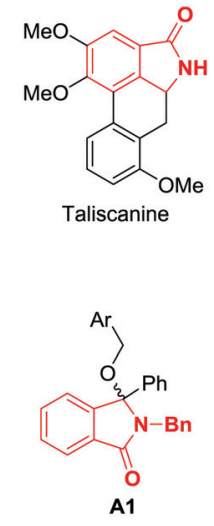


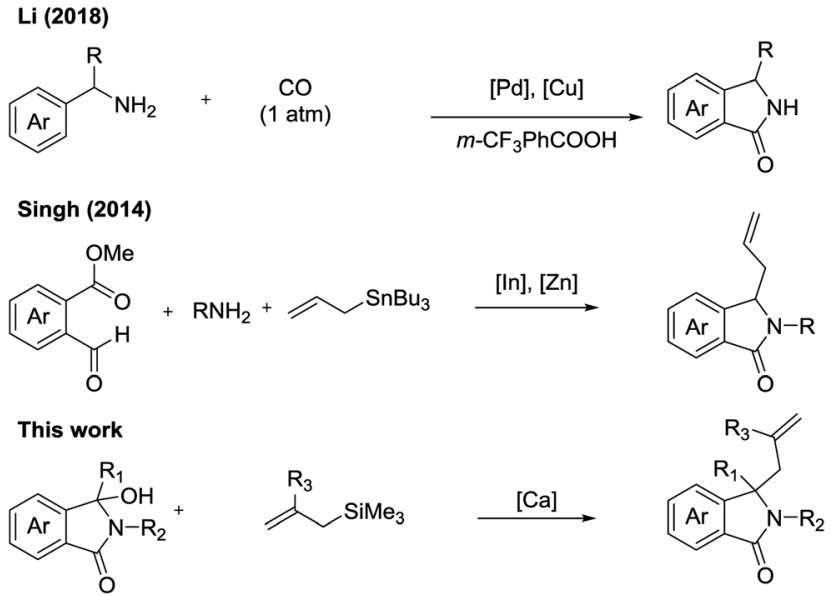

Fig. 2 Selected previous examples.

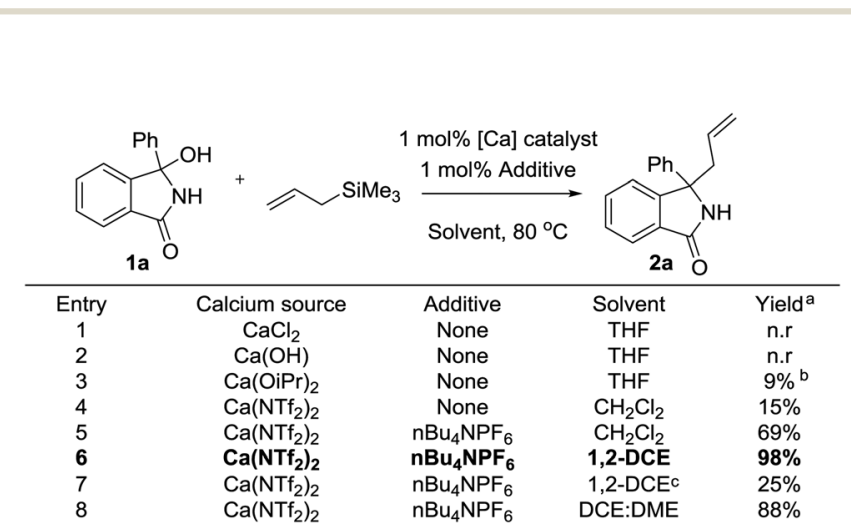

Fig. 3 Optimisation studies. ${ }^{a}$ Isolated yield ${ }^{b} 10$ mol\% used ${ }^{c}$ reaction at room temp.

electron donating (2a,d) and electron withdrawing (2b,c) groups were well tolerated, each providing the allylated product in excellent yields and high efficiency.

We next moved our attention onto compounds exhibiting a range of substitution patterns, with ortho (2e), meta (2f) and ortho/para (2g) substituents all tolerated well. As compounds of this class have been shown to exhibit a range of biological activities, ${ }^{16}$ we next turned our attention to heterocyclic moieties. As shown, the catalyst system is unaffected by traditionally difficult functional groups, with morpholine (2h), furan (2i), and thiophene (2j) all working well. Furthermore, acetal (2k) was also tolerated, affording the allylated product in high yield. All the examples shown thus far contained a free $\mathrm{NH}$ embedded within the lactam core. We therefore decided to investigate the effect of nitrogen substitution has on the reaction. We focused our attention on either easily removable groups (-Me, -Bn) or $N$-allyl group. As shown, these examples also worked well, efficiently providing the desired allylated produce in high yields.

Our focus then turned to the use of branched allyl silanes, as these will produce compounds with increased levels of diversity $\left(\mathrm{R}_{3}=\mathrm{Me}\right.$ or $\left.4-\mathrm{BrPh}\right)$. The reactions once again proceeded smoothly, affording the disubstituted $\gamma$-lactams good yield (Fig. 5 and 6).

With the substrate scope completed, we next decided to investigate the synthetic applicability of our synthesised compounds.

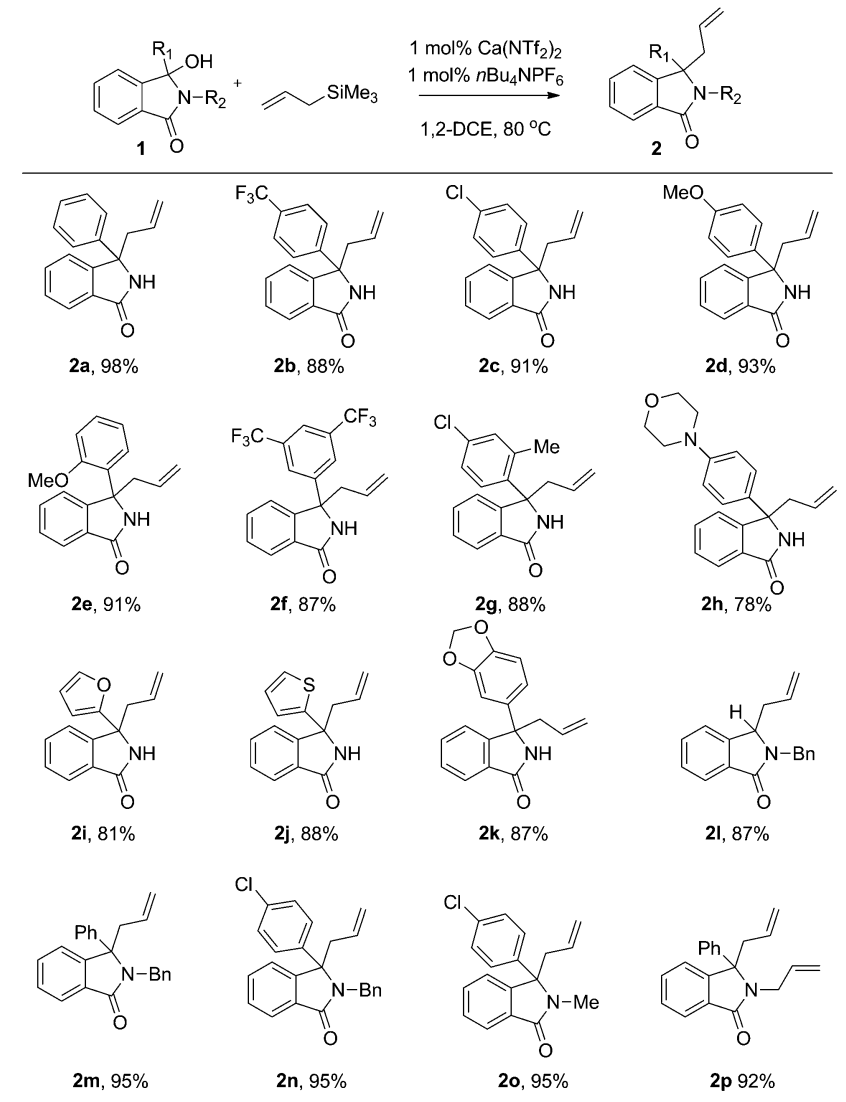

Fig. 4 Substrate scope.

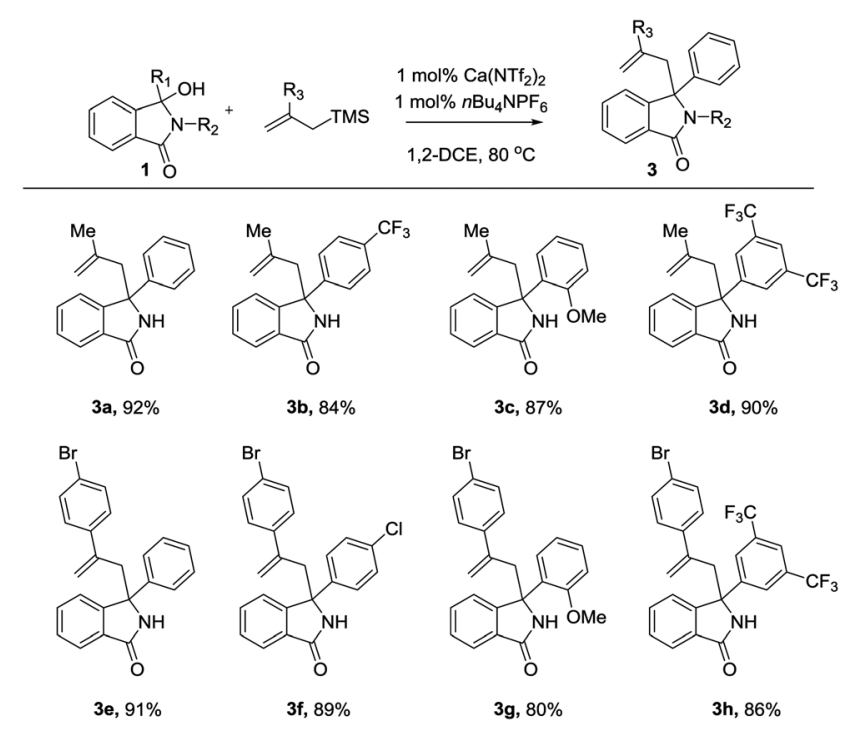

Fig. 5 Branched allylated products.

Employing Buchwald's system for Suzuki cross couplings of aryl chlorides (2o), ${ }^{17}$ and using commercial boronic acid 4, 5 was obtained in excellent yield (Scheme 1).

Indolizidines are privileged scaffolds within medicinal chemistry and new routes towards these important scaffolds remains a priority. ${ }^{18}$ We reasoned that due to the high level of 
<smiles>C=CCC1(c2ccc(Cl)cc2)c2ccccc2C(=O)N1C</smiles><smiles>COc1ccsc1</smiles>

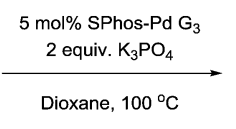

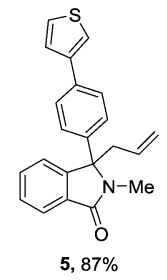

$5,87 \%$
Scheme 1 Suzuki cross coupling

structural diversity achieved via this methodology, ${ }^{19}$ we could produce these important scaffolds easily and in high yields. Using $2 \mathbf{p}$ as a model, we initially performed a ring closing metathesis with Grubb's 1st generation catalyst. ${ }^{20}$ This proceeded well and in expected high yield (Scheme 2). To further increase the utility, we performed the reaction in a one-pot fashion. Once again this produced the desired compound (6) in nearly identical yield to that observed with the isolated.

Finally, as the Hosomi-Sakurai reaction is traditionally noncatalytic, ${ }^{21}$ we wanted to perform preliminary studies to elucidate the potential mechanism of the reaction. The reaction proceeded slowly in the absence of $n \mathrm{Bu}_{4} \mathrm{NPF}_{6}$, suggesting the crucial role the weakly coordinating $\mathrm{PF}_{6}{ }^{-}$ligand has. Furthermore, analysis of the crude reaction mixture by ${ }^{1} \mathrm{H}$ NMR showed the presence of TMS$\mathrm{OH}$. Taken together, as well as inferring from previous studies, ${ }^{22}$ a plausible reaction mechanism is present below.

The active catalyst $\mathbf{A}$ is produced which reacts with the Lewis basic hydroxyl group. The resultant $N$-acyliminium ion B is produced, along with a postulated calcium alkoxy species $\mathbf{C}$. The $N$-acyliminium ion is then attacked by the allyl silane affording the stabilised cation $\mathbf{D}$. We then reason that due to the nucleophilic nature of the ligands in calcium complex $\mathbf{C}$, a facile elimination with concomitant reintroduction of $\mathrm{PF}_{6}{ }^{-}$ occurs, providing the desired compound, releasing TMSOH and regenerating catalyst $\mathbf{A}$.

In summary, we have developed a facile and high yielding calcium catalysed Hosomi-Sakurai reaction. The reaction proceeds well, and is unencumbered by both steric and electronic factors. Furthermore, we have shown that both linear and branched silanes can react, providing much needed diversity of structure. Synthetic applicability has been demonstrated, and a plausible reaction mechanism proposed.

This work was supported by a Research Accelerator Grant from Manchester Metropolitan University. MML thanks MMU for startup funding. AJB thanks the Royal Society of Chemistry for an Undergraduate Research Bursary. We thank Liban Van Haren and Anthony Kromodimedjo for synthetic assistance.
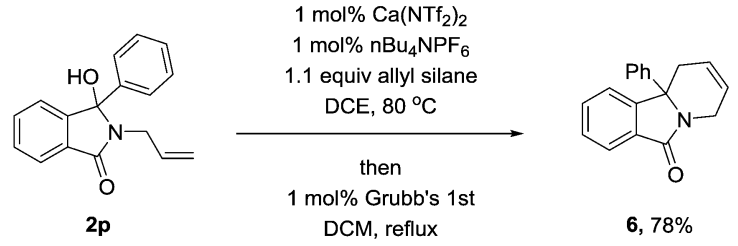

Scheme 2 One pot synthesis of indolizidines.

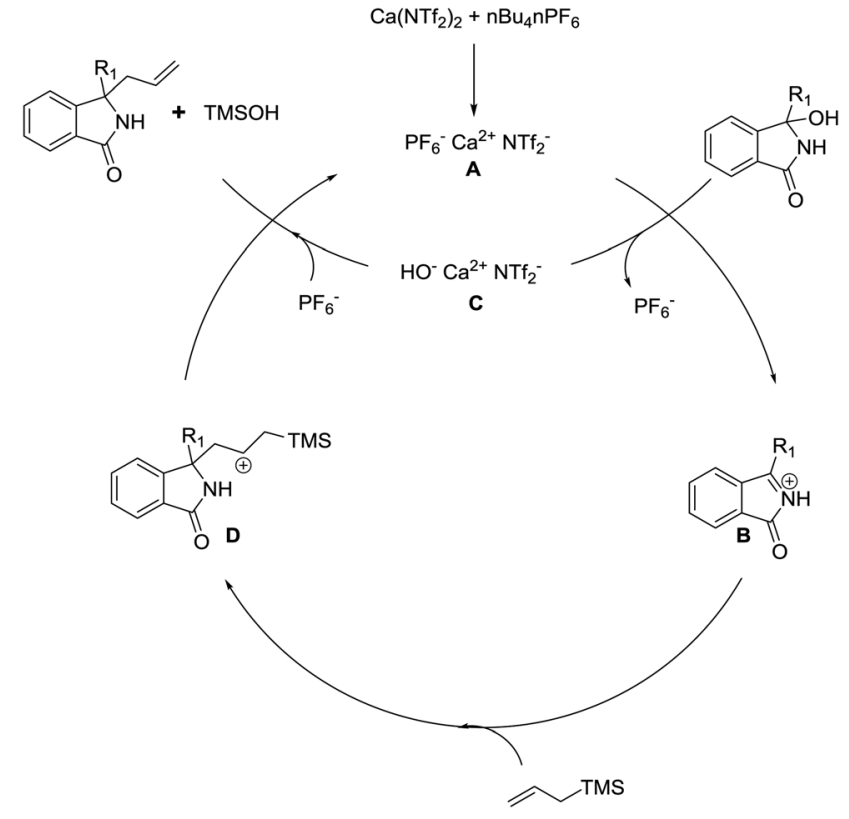

Fig. 6 Plausible mechanism.

\section{Conflicts of interest}

There are no conflicts to declare.

\section{Notes and references}

1 K. Speck and T. Magauer, Beilstein J. Org. Chem., 2013, 9, 2048-2078.

2 X. Armoiry, G. Aulagner and T. Facon, J. Clin. Pharm. Ther., 2008, 33, 219-226.

3 H. A. Priestap, Phytochemistry, 1985, 24, 849-852.

4 I. R. Hardcastle, S. U. Ahmed, H. Atkins, G. Farnie, B. T. Golding, R. J. Griffin, S. Guyenne, C. Hutton, P. Källblad, S. J. Kemp, M. S. Kitching, D. R. Newell, S. Norbedo, J. S. Northen, R. J. Reid, K. Saravanan, H. M. G. Willems and J. Lunec, J. Med. Chem., 2006, 49, 6209-6221.

5 (a) M.-D. Chen, X. Zhou, M.-Z. He, Y.-P. Ruan and P.-Q. Huang, Tetrahedron, 2004, 60, 1651-1657; (b) D. L. Comins, S. Schilling and Y. Zhang, Org. Lett., 2005, 7, 95-98; (c) T. R. Belliotti, W. A. Brink, S. R. Kesten, J. R. Rubin, D. J. Wustrow, K. T. Zoski, S. Z. Whetzel, A. E. Corbin, T. A. Pugsley, T. G. Heffner and L. D. Wise, Bioorg. Med. Chem. Lett., 1998, 8, 1499-1502; (d) Y. Tian, J. Sun, K. Zhang, G. Li and F. Xu, Synthesis, 2018, 2255-2265; (e) D. Brahmchari, A. K. Verma and S. Mehta, J. Org. Chem., 2018, 83, 3339-3347; $(f)$ C. Alonso, M. González, F. Palacios and G. Rubiales, J. Org. Chem., 2017, 82, 6379-6387; (g) J. Maury, G. Force, B. Darses and D. Lebœuf, Adv. Synth. Catal., 2018, 360, 2752-2756.

6 (a) R. B. Bedford, J. G. Bowen and C. Méndez-Gálvez, J. Org. Chem., 2017, 82, 1719-1725; (b) H. S. P. Rao and A. V. B. Rao, J. Org. Chem., 2015, 80, 1506-1516; (c) S. R. Chemler, Beilstein J. Org. Chem., 2015, 11, 2252-2253.

7 (a) C. Zhang, Y. Ding, Y. Gao, S. Li and G. Li, Org. Lett., 2018, 20, 2595-2598; (b) W. Chen, L. Jin, Y. Zhu, X. Cao, L. Zheng and W. Mo, Synlett, 2013, 1856-1860.

8 Z.-Q. Wang, C.-G. Feng, M.-H. Xu and G.-Q. Lin, J. Am. Chem. Soc., 2007, 129, 5336-5337.

9 L. Shi, L. Hu, J. Wang, X. Cao and H. Gu, Org. Lett., 2012, 14, 1876-1879.

10 (a) S. Dhanasekaran, V. Bisai, R. A. Unhale, A. Suneja and V. K. Singh, Org. Lett., 2014, 16, 6068-6071; (b) S. Dhanasekaran, A. Suneja, V. Bisai and V. K. Singh, Org. Lett., 2016, 18, 634-637; (c) C. Qi, V. Gandon and D. Lebœuf, Adv. Synth. Catal., 2017, 359, 2671-2675. 
11 D. D. Carolina, J. B. Eliezer and A. M. F. Carlos, Mini-Rev. Med. Chem., 2007, 7, 1108-1119.

12 H. J. Kiely-Collins, I. Sechi, P. E. Brennan and M. G. McLaughlin, Chem. Commun., 2018, 54, 654-657.

13 (a) C. Masusai, D. Soorukram, C. Kuhakarn, V. Reutrakul and M. Pohmakotr, Eur. J. Org. Chem., 2018, 160-169; (b) T. Bootwicha, D. Panichakul, C. Kuhakarn, S. Prabpai, P. Kongsaeree, P. Tuchinda, V. Reutrakul and M. Pohmakotr, J. Org. Chem., 2009, 74, 3798-3805; (c) R. D. Dura, I. Modolo and L. A. Paquette, Heterocycles, 2007, 74, 145; (d) I. Osante, E. Lete and N. Sotomayor, Tetrahedron Lett., 2004, 45, 1253-1256.

14 D. Lebœuf, M. Presset, B. Michelet, C. Bour, S. Bezzenine-Lafollée and V. Gandon, Chem. - Eur. J., 2015, 21, 11001-11005.

15 (a) M. Niggemann and M. J. Meels, Angew. Chem., Int. Ed., 2010, 49, 3684-3687; (b) J. M. Begouin and M. Niggemann, Chem. - Eur. J., 2013, 19, 8030-8041; (c) J.-M. Begouin, F. Capitta, X. Wu and M. Niggemann, Org. Lett., 2013, 15, 1370-1373; (d) L. Fu and M. Niggemann,
Chem. - Eur. J., 2015, 21, 6367-6370; (e) S. Gao, T. Stopka and M. Niggemann, Org. Lett., 2015, 17, 5080-5083; $(f)$ V. J. Meyer, C. Ascheberg and M. Niggemann, Chem. - Eur. J., 2015, 21, 6371-6374; (g) T. Stopka and M. Niggemann, Org. Lett., 2015, 17, 1437-1440; (h) V. J. Meyer and M. Niggemann, Eur. J. Org. Chem., 2011, 3671-3674. 16 J. Caruano, G. G. Muccioli and R. Robiette, Org. Biomol. Chem., 2016, 14, 10134-10156.

17 M. A. Düfert, K. L. Billingsley and S. L. Buchwald, J. Am. Chem. Soc., 2013, 135, 12877-12885.

18 J. P. Michael, Nat. Prod. Rep., 2007, 24, 191-222.

19 A. K. Maity and S. Roy, J. Org. Chem., 2012, 77, 2935-2941.

20 (a) P. Schwab, M. B. France, J. W. Ziller and R. H. Grubbs, Angew. Chem., Int. Ed. Engl., 1995, 34, 2039-2041; (b) P. Schwab, R. H. Grubbs and J. W. Ziller, J. Am. Chem. Soc., 1996, 118, 100-110.

21 J. J. Lade, S. D. Pardeshi, K. S. Vadagaonkar, K. Murugan and A. C. Chaskar, $R S C$ Adv., 2017, 7, 8011-8033.

22 J. Davies and D. Leonori, Chem. Commun., 2014, 50, 15171-15174. 